\title{
APPEARANCE AND DISTRIBUTION OF TISSUE REMODELLATION FACTORS IN THE HARD TISSUE OF PATIENTS AFFECTED BY CLEFT LIP PALATE
}

\author{
Dace Buile ${ }^{1, \#}$, Māra Pilmane ${ }^{1}$, and llze Akota ${ }^{2}$ \\ ${ }^{1}$ Institute of Anatomy and Anthropology, Rīga Stradiṇš University, 9 Kronvalda Str., LV-1010, Rīga, LATVIA \\ ${ }^{2}$ Institute of Stomatology, Rīga Stradinš̌ University, 20 Dzirciema Str., LV-1007, Rīga, LATVIA \\ \# Corresponding author, dace.danberga@gmail.com
}

Contributed by Māra Pilmane

\begin{abstract}
Bone repair after surgical intervention on cleft lip palate $(C L P)$ depends on the coordinated action of multiple tissue regeneration factors. We determined the relative number and appearance of tissue factors: matrix metalloproteinase-2 (MMP-2), tissue inhibitor of metalloproteinase-2 (TIMP-2), bone morphogenetic protein 2/4 (BMP 2/4), transforming growth factor beta (TGF-B), Wnt3a protein (Wnt3a), Runt-related transcription factor 2 (Runx2), basic fibroblast growth factor (bFGF) and osteoprotegerin in hard tissue of CLP patients during first time surgical intervention. Fourtythree CLP patients with 24 bone and 36 cartilage samples were involved. Immunohistochemistry was used to assess the levels of tissue factors and the semi-quantitative census method was used for quantification of immunological structures. The increased amount of MMP-2 and bFGF positive cells was detected in the CLP group in cartilage and bone $(p<0.05)$, compared to the controls. A statistically significant $(p=0.012)$ increased amount of BMP $2 / 4$ positive cells was found in cartilage of CLP patients, in comparison to the control group. Increased appearance of MMP-2, bFGF in hard tissue of the CLP patients indicates the predominance of tissue degradation. Increased number of BMP2/4 positive chondrocytes suggests improved cartilage growth and better regeneration in CLP patients.
\end{abstract}

Key words: growth factors, human.

\section{INTRODUCTION}

Cleft lip palate (CLP) belongs to serious facial deformations and occurs during embryogenesis, when the mesenchyme in the lateral palatine process fails to fuse with the intermaxillary segment (Norton, 2016, pp. 1-24). CLP incidence in the world is approximately one in 1000 newborns (Murray, 2002), in comparison to data from Latvia where incidence is one in 700 newborns (Akota et al., 2001). The facial skeleton is composed of two types of tissue: cartilage and bone that are formed by chondrocytes and osteoblasts. Given that they share a common progenitor, it is important to understand which signalling pathways control the differentiation into bone and cartilage (Hartmann, 2006). Overall, CLP affects development of speech and hearing, breathing through the nose, olfactory function, eating, and is an aesthetic defect. Until this moment, surgical therapy is the method of choice for cleft palate correction, and the need for multiple surgeries is common (Tiwana et al., 2018). There are many signal molecules, growth and remodellation factors, and genes involved in the development of facial clefts and the process of tissue healing after surgery. While studies about signal molecules and tissue factors are found in the literature, most have investigated animal tissue, and significantly less studies can be found about human tissue.

Matrix metalloproteinases (MMPs) and tissue inhibitors of matrix metalloproteinases (TIMPs) are responsible for tissue remodellation in the process of craniofacial development. Additionally, degradation of extracellular matrix (ECM) by the MMPs stimulate cell proliferation and migration (Letra et al., 2012). MMP-2 and MMP-9 are two proteases that have major activity in ECM degradation and are involved in degradation of type IV collagen as well as laminin - major components of basal membranes. In addition, they are also associated in a variety of processes like 
bone remodelling, angiogenesis, immune response and tissue repair. Since these MMPs are secreted as proenzymes that require activation, their tissue distribution may not necessarily reflect the sites of enzymatic activity (Gkantidis et al., 2012). Loss of MMP in mice impairs tooth root formation, alveolar bone remodelling, and periodontal ligament formation and integration into alveolar bone (Xu et al., 2016).

TIMPs are also secreted into the ECM and have the ability to inhibit the activity of MMPs. In addition, TIMPs are considered to exert pluripotential effects on cellular behaviour such as cell growth, survival, migration, and differentiation, independently of their MMP neutralising functions. From the early stages of molar tooth development, location of TIMP-2 has been shown to be associated with the ECM presented in the jaw mesenchyme on the lingual side of the molar germ and along the lingual side of the dental basement membrane (Yoshiba et al., 2007). Changed relations in the amount in favour of the TIMPs level can also be found in the tissue of the CLP (Verstappen et al., 2006).

Bone morphogenetic proteins (BMPs) are multifunctional growth factors that mediate a variety of biological functions essential for gastrulation, organogenesis and embryonic and postnatal growth. BMPs also have an important role in the development of cranial neural crest, facial primordia, teeth, lips and palate. It is responsible for the migration of cells in the neural crest, which give rise to most of the craniofacial structures (Xuguang et al., 2006). The BMPs signal controls cell division in the anterior palatal mesenchyme. Experiments on mice showed that BMP receptor inactivation in mesenchyme of maxillary bone could result in cleft lip and palate (Li et al., 2013). Release of BMP-2 incorporated in an implant increased callus mineralisation and bone healing in the tibial bone (Faßbender et al., 2014).

Transforming growth factor $\beta$ (TGF- $\beta$ ) stimulates the production of collagen, fibronectin, proteoglycans and inhibits collagen degradation by both decreasing MMP activity and increasing the activity of TIMPs (Kumar et al, 2014, Chapt. 1, pp. 1-29). TGF- $\beta$ activates MMPs that are located in the midline epithelium of palatal bones and participates in the fusing of palatal bones (Li et al., 2017). Bone ECM is the major storage site in the body for TGF- $\beta$ and it can be released and activated by resorbing osteoclasts, resulting in the inhibition of osteoclast formation, activity and stimulation of mature osteoblasts to produce bone matrix proteins, although the molecular mechanism by which the TGF- $\beta$ is released from ECM-bound stores remain unclear (Dallas et al., 2002).

Fibroblast growth factors (FGFs) are members of a large family of signalling proteins. FGF signalling participates in all stages of development of palate, especially in the cell proliferation of the palate shelves. Sonic hedgehog (Shh) signalling is believed to be responsible for cell proliferation in the palate mesenchyme, and Shh signalling works together with the FGF signalling via coordinated epithelialmesenchymal interactions (Weng et al., 2018). FGFs also have proved to be important in the regulation of chondrocyte proliferation and initiation of chondrocyte hypertrophy (Logan et al., 2004). Basic fibroblast growth factor (bFGF) is a member of the FGF family and bFGF signalling does not directly induce osteoblast differentiation, but is known to modulate osteoblast differentiation. However, the exact mechanism of the bFGF signalling in bone healing or regeneration has not been explained (Charoenlarp et al., 2017).

Wnt3a is a signalling molecule that belongs to the Wnt protein family and is included in various skeletogenous processes, including cellular differentiation of the chondro-osseous progenitor cells, regulation of proper chondrocyte columns in growth plate and migration processes (Logan et al., 2004). Signalling of the Wnt results with Runx2 promoter activation and induces endogenous Runx 2 gene expression in pluripotent mesenchymal cells that later take a part into bone formation (Gaur et al., 2005).

Runt-related transcription factor 2 (Runx2) belongs to the Runx family and is a transcription factor needed for the correct structure of osteoblast cells. The BMPs and the FGFs regulate transcription of Runx2. Runx 2 also induces mesenchymal cell differentiation into immature osteoblasts until the final stage of the process during which maturity of the osteoblasts are inhibited (Komori, 2010; Dos Santos Pereira et al., 2017). A study on Chinese patients showed that normal distribution of the Runx 2 also might be a reason for cranial dysplasia due to the mutation in the Runt domain, which leads the impaired transaction activities of Runx2 (Zhang et al., 2017).

Osteoprotegerin (OPG) is a protein of the Tumour Necrosis Factor (TNF) cell signalling protein family. It is the main osteoclastogenesis modulator, also known as inhibitor of terminal differentiation and activation of osteoclasts (Hsu et al., 2005). OPG interacts with receptor activator of nuclear factor $\kappa \mathrm{B}$ ligand (RANKL) by inhibiting binding of the RANKL to the RANK, and therefore resulting in osteoclastogenesis and inhibited bone resorption (Kwan et al., 2008). Another study confirmed that the OPG during the osteoclastogenesis enhanced the size of osteoclasts, but attenuated their bone resorbing activity, suggesting that the OPG may play an auto regulatory role in a late phase of the osteoclastogenesis through the induction of apoptosis (Kang et al., 2014). Promising results exist in the therapy for periodontitis affected tissue in rabbits. The study demonstrated that the periodontal ligament stem cells (PDLSCs) of gene-modified rabbits expressing human OPG achieved an earlier mineralisation and more bone formation, which might help to ensure the reconstruction of alveolar bone defect (Su et al., 2015).

Based on all the information mentioned above, it is thought that remodellation factors have importance in morphopathogenesis of CLP. Also, based on the absence of these tissue factor's correlative research in hard tissue of CLP patients, the aim of our present study is to determine a relative number and appearance of the tissue factors (MMP-2, TIMP-2, 
Table 1. Information on CLP patients

\begin{tabular}{|c|c|c|c|c|c|}
\hline Patient & Age & Surgery procedure & Patient & Age & Surgery procedure \\
\hline No. 1 & 5 years 7 months & Rhinoplasty & No. 22 & 13 years 9 months & Rhinoplasty \\
\hline No. 2 & 6 years 7 months & Rhinoplasty & No. 23 & 13 years 9 months & Rhinoplasty \\
\hline No. 3 & 7 years 3 months & Alveolar osteoplasty & No. 24 & 14 years 4 months & Rhinoplasty \\
\hline No. 4 & 7 years 5 months & Rhinoplasty & No. 25 & 14 years 5 months & Rhinoplasty \\
\hline No. 5 & 7 years 7 months & Rhinoplasty & No. 26 & 15 years & Rhinoplasty \\
\hline No. 6 & 8 years 3 months & Rhinoplasty & No. 27 & 15 years 10 months & Rhinoplasty \\
\hline No. 7 & 8 years 5 months & Alveolar osteoplasty & No. 28 & 16 years & Rhinoplasty \\
\hline No. 8 & 8 years 7 months & Rhinoplasty & No. 29 & 16 years 3 months & Rhinoplasty \\
\hline No. 9 & 8 years 11 months & Alveolar osteoplasty & No. 30 & 16 years 6 months & Rhinoplasty \\
\hline No. 10 & 9 years 5 months & Alveolar osteoplasty & No. 31 & 16 years 7 months & Rhinoplasty \\
\hline No. 11 & 9 years 6 months & Rhinoplasty & No. 32 & 16 years 10 months & Rhinoplasty \\
\hline No. 12 & 9 years 11 months & Alveolar osteoplasty & No. 33 & 17 years & Rhinoplasty \\
\hline No. 13 & 12 years 7 months & Rhinoplasty & No. 34 & 18 years & Rhinoplasty \\
\hline No. 14 & 12 years 8 months & Rhinoplasty & No. 35 & 18 years & Rhinoplasty \\
\hline No. 15 & 12 years 8 months & Rhinoplasty & No. 36 & 18 years 7 months & Rhinoplasty \\
\hline No. 16 & 12 years 11 months & Rhinoplasty & No. 37 & 18 years 8 months & Alveolar osteoplasty \\
\hline No. 17 & 12 years 11 months & Rhinoplasty & No. 38 & 18 years 8 months & Alveolar osteoplasty \\
\hline No. 18 & 12 years 11 months & Rhinoplasty & No. 39 & 18 years 8 months & Alveolar osteoplasty \\
\hline No. 19 & 13 years 1 month & Rhinoplasty & No. 40 & 18 years 8 months & Alveolar osteoplasty \\
\hline No. 20 & 13 years 5 months & Rhinoplasty & No. 41 & 18 years 8 months & Alveolar osteoplasty \\
\hline No. 21 & 13 years 9 months & Rhinoplasty & No. 42 & 21 years 1 month & Rhinoplasty \\
\hline
\end{tabular}

BMP 2/4, TGF-3, bFGF, Wnt3a, Runx2, and OPG) in hard tissue (bone and cartilage) of CLP patients during the first plastic alveolar osteoplasty and rhinoplasty.

\section{MATERIALS AND METHODS}

Patients. Tissue samples were obtained during first time CLP correction surgeries, such as alveolar osteoplasty and rhinoplasty, in the Cleft Lip and Palate Centre of the Institute of Stomatology of the Rīga Stradiņš University (RSU). The research involved 43 patients with CLP between the ages of 5 years 7 months to 21 years and 1 month with 24 bone tissue and 36 cartilage tissue samples (see Table 1). Control material of bone was obtained from seven healthy patients from the facial cleft during unrelated surgical operations, due to the ethical difficulties related to receiving permission from parents for the usage of tissue (see Table 2). Due to the ethical considerations there was no possibility to obtain hyaline cartilage from children with facial cleft unrelated surgeries, and therefore cartilage tissue from trachea was obtained from the exposition of RSU Institute of Anatomy and Anthropology (AAI) from subjects between the ages of 20 to 40 years. The study was approved by the local Ethical Committee of the Rìga Stradiņ̌s University.

Methods. The material from patients obtained during the first CLP correction surgery was fixated in transport test tubes with Stefanini (Zamboni) solution and delivered to the RSU AAI Laboratory of Morphology for further processing. After tissue fixation, the material was rinsed for 24 hours in Tyrode solution. An alcohol solution was used for tissue de-
Table 2. Information about the control group for bone

\begin{tabular}{ccc}
\hline Patient & Age & Surgery procedure \\
\hline No. 1 & 6 years 9 months & Tooth extraction \\
No. 2 & 9 years 9 months & Tooth extraction \\
No. 3 & 10 years 2 months & Tooth extraction \\
No. 4 & 10 years 5months & Tooth extraction \\
No. 5 & 11 years 7 months & Tooth extraction \\
No. 6 & 12 years 8 months & Tooth extraction \\
No. 7 & 14 years 5 months & Tooth extraction
\end{tabular}

watering, and tissue was placed in xylene for 30 minutes for degreasing. The tissue was placed into paraffin for one and two hours for the hardening process. Tissue blocks were cut in $3 \mu$ sections with a semi-automatic rotary microtome (Leica RM2245, Leica Biosystems Richmond Inc., United States). The sections were fixed on slides and dried in a thermostat, later re-dewaxed in xylene, and dehydrated in various alcoholic solutions.

Firstly, tissue sections were dyed with haematoxylin and eosin for a general overview. Afterwards, for the expression of genes and proteins we used the immunohistochemistry method. Tissue selections were stained and processed for the following antibodies: MMP-2 (code: ORB101049, rabbit, 1:400, Biorbyt USA), TIMP-2 (code: SC-21735, mouse, 1:50, Santa Cruz USA), BMP 2/4 (code: AF355, goat, 1:100, R/D Germany), TGF31 (code: ORB7087, rabbit, 1:200, Biorbyt USA), bFGF (code: AB16828, rabbit, 1:200, Abcam GB), Wnt3a (code: AB1992, rabbit, 1:800, Abcam 
GB), Runx2 (code: AB192256, rabbit, 1:250, Abcam GB) and OPG (code A0611, rabbit, 1:100, The Orbit USA).

For quantification of immunological structures we used the semi-quantitative census method (Pilmane, 1997) as follows: $(0)$ - no positive structure was detected in the visual field $(0 /+)$ - occasional positive structures seen in the visual field, $(+)$ - few positive structures seen in the visual field, $(+/++)-$ few to moderate number of positive structures seen in the visual field, $(++)-$ moderate number of positive structures seen in the visual field, $(++/+++)-$ moderate to numerous positive structures seen in the visual field, $(+++)-$ numerous positive structures seen in the visual field, $(+++/++++)$ - numerous to abundant positive structures seen in the visual field, $(++++)-$ abundance of positive structures seen in the visual field.

Statistical analysis of the data. For the statistical analysis the SPSS 21.0 software version (IBM Corp., Armonk, NY, USA) was used. Spearman's rank correlation coefficient (rs) was calculated for determination of correlations between values. The results were interpreted: $r s=0.4-0.59-$ moderate, positive correlation, and $\mathrm{rs}=0.6-0.79-$ strong, positive correlation. The Mann-Whitney U-test was performed for the comparison of study groups; $p$ value $<0.05$ was considered to be statistically significant.

\section{RESULTS}

OPG. OPG-positive cells were detected in all bone and cartilage tissue samples from the CLP and the control group. The number of the OPG-positive osteocytes in both the control group and the CLP group was very variable, from occasional to numerous, but no statistically significant difference in median numbers was found between the CLP and the control group ( $\mathrm{U}=63.0 ; p=0.610)$. The number of the OPG-positive chondrocytes in the control group varied from moderate to abundance, while in the CLP group it varied from occasional to abundance (Fig. 1a) (see Table 3). There was no statistically significant difference in the median numbers of the OPG positive chondrocytes between the CLP and the control group ( $\mathrm{U}=105.0 ; p=0.051)$.

TGF-ß3. TGF- $\beta$ positive osteocytes were observed in all bone and cartilage samples. Few to numerous TGF- $\beta$ positive osteocytes were present in the control group, while in the CLP group the number of TGF- $\beta$-positive cells varied from occasional to numerous. No statistically significant difference in median value between the CLP group and the control group was found $(\mathrm{U}=37.0 ; p=0.061)$. The number of TGF- $\beta$-positive chondrocytes in the control group varied from few to moderate number to abundance, while in the CLP group it varied from occasional to abundance (Fig. 1b) (see Table 3). However, there was no significant difference in median numbers of TGF- 3 -positive chondrocytes between the CLP and the control group $(\mathrm{U}=166.0 ; p=$ $0.480)$.
Runx2. Mainly there was an absence of Runx2-positive osteocytes in the control group in comparison to the CLP group, in which the absence of the Runx 2 expression was observed only in three bone tissue samples, but relative number of Runx2-positive cells ranged up to few. There was no significant difference in the median numbers of Runx2-positive cells between the groups $(\mathrm{U}=41.0$; $p=$ $0.073)$. The number of Runx2-positive chondrocytes in the control group varied from few to numerous, while in the CLP group it varied from occasional to abundance (Fig. 1c) (see Table 3). No statistically significant difference in median numbers between the groups was found $(\mathrm{U}=182.5$; $p=0.903)$.

Wnt3a. Wnt3a-positive cells were not detected in the specimens and the appearance of Wnt3a-positive osteocytes ranged up to moderate number in both the CLP and the control group (Fig. 1d) (see Table 3). The median number of Wnt3a-positive osteocytes was few in the control group and occasional to few in the CLP group, but there was no statistically significant difference between the groups in general $(\mathrm{U}=66.5 ; p=0.378)$. In comparison to bone specimens, Wnt3a-positive chondrocytes were found in all cartilage tissue samples. Moderate number to abundant Wnt3a-positive chondrocytes were present in the control group, while in the CLP group the number of Wnt3a-positive structures varied from few to abundance, showing no statistically significant difference in median value between the study groups $(\mathrm{U}=$ $154.5 ; p=0.377)$.

TIMP-2. TIMP-2-positive cells were detected in all specimens. The number of TIMP-2-positive osteocytes in the control group varied from occasional to numerous, while in the CLP group it varied from occasional to moderate. No statistically significant difference in median value was found between the groups $(\mathrm{U}=53.0 ; p=0.169)$. The number of TIMP-2-positive chondrocytes in the control group varied from few to moderate number, to numerous to abundant number, while in the CLP group it varied from few to moderate number, to abundant (Fig. 1e) (see Table $3)$. No statistically significant difference between the groups was found $(\mathrm{U}=160.5 ; p=0.555)$.

bFGF. bFGF-positive cells were observed in all groups. The number of bFGF-positive osteocytes in the control group varied from few to numerous, while in the CLP group it varied from occasional to moderate number. The number of bFGF positive osteocytes was significantly higher in the CLP group than in the control group $(\mathrm{U}=21.5 ; p=0.002)$. The number of bFGF-positive chondrocytes in the control group varied from few to moderate number to moderate number, while in the CLP group it varied from few to abundant (Fig. 1f) (see Table 3). The number of bFG-positive chondrocytes was significantly higher in the CLP group in comparison to the control group $(\mathrm{U}=79.0 ; p=0.005)$.

MMP-2. Generally, there was an absence of MMP-2positive osteocytes in the control group, where moderate number of MMP-2-positive structures was observed only in one specimen, while number of MMP-2-positive structures 

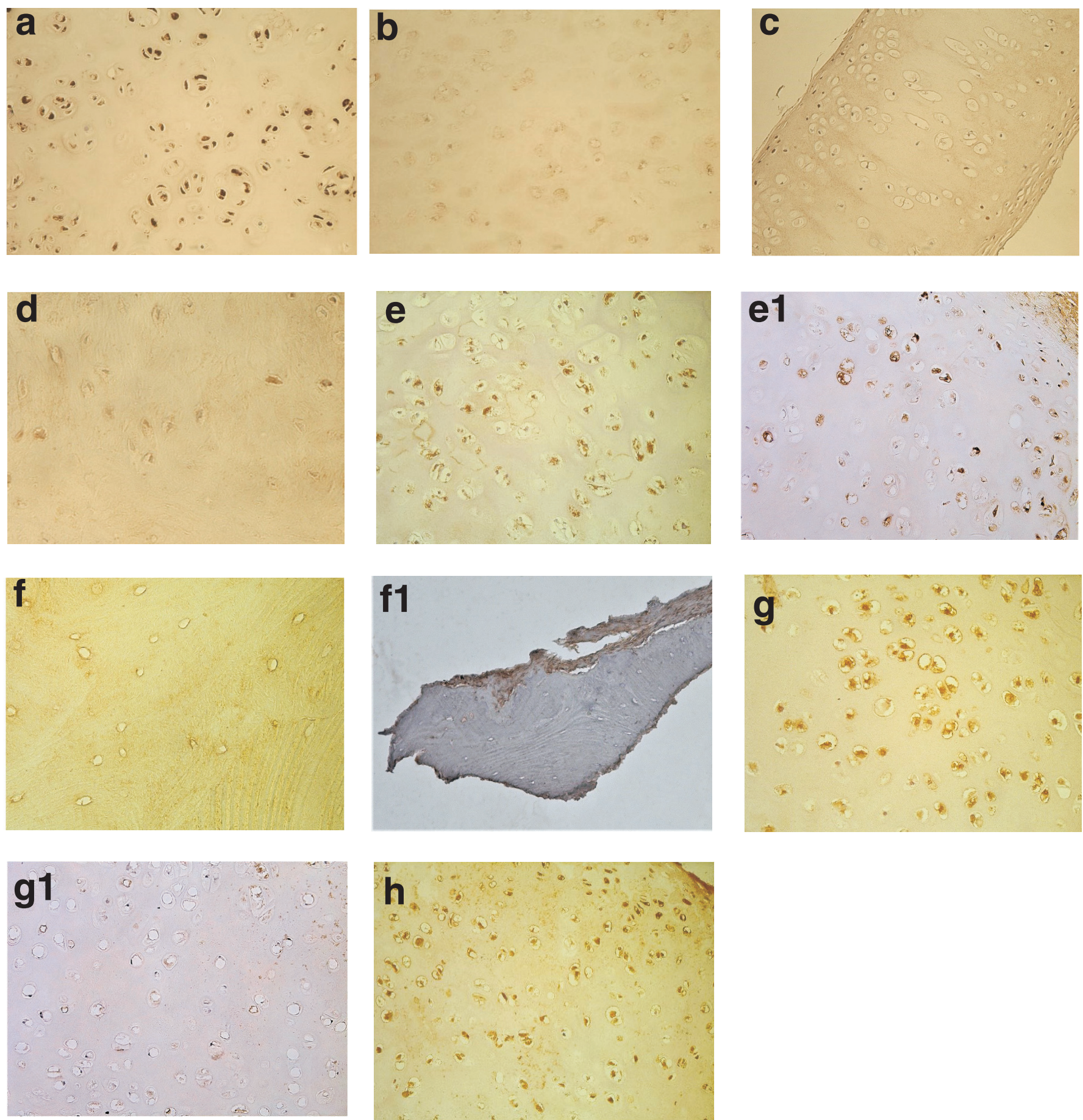

Fig. 1. Microphotographs of a relative number in different factors of hard tissue in cleft-affected patients. (a) Numerous OPG positive chondrocytes observed in the cartilage of 18 years old CLP patient, IMH, $\times 200$. (b) Moderate number of TGF- $\beta$-positive chondrocytes observed in the cartilage of a 13 year and 1 month old CLP patient, IMH, $\times 200$. (c) Moderate number of Runx2-positive chondrocytes observed in the cartilage of a 13 year and 9 months old CLP patient, IMH, $\times 200$. (d) Moderate number of Wnt3a-positive osteocytes observed in the bone of a 12 year and 8 months old CLP patient, IMH, $\times 200$. (e) Numerous bFGF-positive chondrocytes observed in the cartilage of a 12 year and 7 months old CLP patient, IMH, $\times 250$. (e1) Numerous to moderate number of bFGF-positive chondrocytes observed in the cartilage of the control patient, IMH, $\times 250$. (f) No MMP-2-positive osteocytes observed in the bone of a 17 year old CLP patient, IMH, $\times 250$. (f1) No MMP-2-positive osteocytes observed in the bone of a 10 year and 5 months old control patient, IMH, $\times 250$. (g) Numerous BMP 2/4-positive chondrocytes observed in the cartilage of a 5 year and 7 months old CLP patient, IMH, $\times 250$. (g1) Numerous BMP 2/4-positive chondrocytes observed in the cartilage of the control patient, IMH, $\times 250$. (h) Numerous TIMP-2-positive chondrocytes observed in the cartilage of a 12 year and 11 months old CLP patient, IMH, $\times 200$.

in the CLP group varied from occasional to numerous (Fig. 1g) (see Table 3). We observed a significantly higher number of MMP-2-positive osteocytes in the CLP group in comparison to the control group ( $\mathrm{U}=27.5 ; p=0.011)$. The number of MMP-2-positive chondrocytes in the control group varied from few to moderate number to moderate number, while in the CLP group it varied from few to abundant. The number of MMP-2-positive chondrocytes was statistically higher in CLP group when compared to the control group $(\mathrm{U}=91.5 ; p=0.013)$. 
Table 3. Relative number of factor-positive cells in cartilage and bone in the control group and in CLP patients

\begin{tabular}{|c|c|c|c|c|c|c|c|c|}
\hline & OPG & TGF- $\beta$ & Runx2 & Wnt3a & TIMP-2 & bFGF & MMP-2 & BMP $2 / 4$ \\
\hline Control cartilage & $++/+++-++++$ & $++/-+++/++++$ & +-+++ & ++-++++ & $+/++-+++/++++$ & $+/++-+++$ & $+/++-+++$ & $+/++-+++$ \\
\hline Median value & $+++/++++$ & $++-++/+++$ & ++ & $++/+++-+++$ & $++/+++$ & $++/+++$ & ++ & ++ \\
\hline Patient cartilage & $0 /+-++++$ & $0 /+-++++$ & $0 /+-+++/++++$ & +-++++ & $+/++-++++$ & +-++++ & $+/++-++++$ & $0 /+-++++$ \\
\hline Median value & +++ & $++-++/+++$ & ++ & +++ & $++/+++$ & +++ & $++/++++$ & +++ \\
\hline Control bone & $0 /+-+++$ & +-+++ & $0-++$ & $0-++$ & $0 /+-+++$ & +-+++ & $0-++$ & $0-++$ \\
\hline Median value & + & $+/++$ & 0 & $0 /+-+$ & + & $+/++$ & 0 & $0 /+-+$ \\
\hline Patient bone & $0 /+-+++$ & $0 /+-+++$ & $0-+$ & +-++ & $0 /+-++$ & $0 /+-++$ & $0 /+-++$ & $0 /+-++$ \\
\hline Median value & + & $++/+++-+++$ & $0 /+$ & + & $0 /+$ & $0 /+$ & $0 /+$ & + \\
\hline
\end{tabular}

Abbreviations: OPG, osteoprotegerin; TGF-B, transforming growth factor beta; Runx2, Runt-related transcription factor 2; Wnt3a, Wnt3a protein; TIMP-2, tissue inhibitor of metalloproteinase-2; bFGF, basic fibroblast growth factor; MMP-2, matrix metalloproteinase-2; BMP 2/4, bone morphogenetic protein 2/4. Median value - middle number in a sorted list of numbers. Quantification of structures: 0 - no positive structures in the visual field; $0 /+-$ occasional positive structures in the visual field; + - few positive structures in the visual field; $+/++-$ few to moderate positive structures in the visual field; ++ - moderate positive structures in the visual field; $++/+++-$ moderate to numerous positive structures in the visual field; +++- numerous positive structures in the visual field; +++ / ++++ - numerous to abundance positive structures in the visual field.

BMP 2/4. There was an absence of BMP2/4-positive osteocytes in two specimens of the control group, but the results ranged up to moderate number of positive cells, while in the CLP group it varied from occasional to moderate number, showing no significant difference in median value between the CLP and the control group ( $\mathrm{U}=60.0 ; p=0.232)$. The number of BMP2/4-positive chondrocytes in the control group varied from few to moderate number to moderate number, while in the CLP group it varied from occasional to abundant (Fig. 1h) (see Table 3). A significantly lower number of BMP2/4 positive structures was observed in the control group in comparison to the CLP group ( $\mathrm{U}=91.0$; $p=0.012$ ).

Statistical data. Statistically significant $(p<0.05)$ strong $\left(r_{\mathrm{s}}=0.6-0.79\right)$ correlations were found between MMP-2 and TGF- $\beta\left(\mathrm{r}_{\mathrm{s}}=0.602 ; p<0.01\right)$; Runx2 and Wnt $3 \mathrm{a}\left(\mathrm{r}_{\mathrm{s}}=\right.$ 0.625; $p<0.01$ ) in CLP group bone (see Table 4).

Statistically significant $(p<0.05)$ moderate $\left(\mathrm{r}_{\mathrm{s}}=0.40 .59\right)$ correlations were found between MMP-2 and BMP 2/4 ( $\mathrm{r}_{\mathrm{s}}=$

Table 4. Summary of Spearman's rank correlation analysis. Strong and moderate relationships between numbers of positive factors in the bone of the CLP group are shown

\begin{tabular}{lcccc}
\hline \multicolumn{1}{c|}{ Factor 1} & Factor 2 & $\mathrm{r}_{\mathrm{s}}$ & $\mathrm{p}$ \\
\hline MMP-2 & TGF- $\beta$ & 0.602 & $<0.01$ \\
Runx2 & Wnt3a & 0.625 & $<0.01$ \\
MMP-2 & BMP 2/4 & 0.513 & $<0.05$ \\
MMP-2 & bFGF & 0.402 & $<0.05$ \\
MMP-2 & Wnt3a & 0.488 & $<0.05$ \\
MMP-2 & OPG & 0.546 & $<0.01$ \\
TIMP-2 & Wnt3a & 0.588 & $<0.01$ \\
BMP 2/4 & Wnt3a & 0.564 & $<0.01$ \\
bFGF & TGF- 3 & 0.504 & $<0.05$ \\
TGF- 3 & Wnt3a & 0.516 & $<0.05$ \\
TGF- 3 & OPG & 0.578 & $<0.05$ \\
OPG & Wnt3a & 0.516 & $<0.05$
\end{tabular}

For abbreviations see Table 3 .
0.513; $p<0.05)$; MMP-2 and bFGF $\left(\mathrm{r}_{\mathrm{s}}=0.402 ; p<0.05\right)$; MMP-2 and Wnt3a $\left(\mathrm{r}_{\mathrm{s}}=0.488 ; p 0.05\right)$; MMP-2 and OPG $\left(\mathrm{r}_{\mathrm{s}}=0.546 ; p 0.01\right)$; TIMP-2 and Wnt3a $\left(\mathrm{r}_{\mathrm{s}}=0.588 ; p<\right.$ $0.01)$; TIMP-2 and TGF- $\beta\left(\mathrm{r}_{\mathrm{s}}=0.464 ; p<0.01\right)$; TIMP-2 and BMP 2/4 $\left(\mathrm{r}_{\mathrm{s}}=0.440 ; p<0.05\right)$; BMP 2/4 and Wnt3a $\left(\mathrm{r}_{\mathrm{s}}=0.564 ; p<0.01\right) ; \mathrm{bFGF}$ and TGF- $\beta\left(\mathrm{r}_{\mathrm{s}}=0.504, p<\right.$ $0.05)$; TGF- $\beta$ and Wnt $3 \mathrm{a}\left(\mathrm{r}_{\mathrm{s}}=0.516 ; p<0.05\right)$; TGF- $\beta$ and OPG $\left(\mathrm{r}_{\mathrm{s}}=0.578 ; p<0.05\right)$; OPG and Wnt3a $\left(\mathrm{r}_{\mathrm{s}}=0.516 ; p<\right.$ $0.05)$ in the bone of the CLP group.

Statistically significant $(p<0.05)$ strong $\left(\mathrm{r}_{\mathrm{s}}=0.6-0.79\right)$ correlations were found between MMP-2 and bFGF $\left(\mathrm{r}_{\mathrm{s}}=0.612\right.$; $p<0.01)$; TIMP-2 and TGF- $\beta\left(\mathrm{r}_{\mathrm{s}}=0.663 ; p<0.01\right)$; TIMP-2 and BMP 2/4 $\left(\mathrm{r}_{\mathrm{s}}=0.631 ; p<0.01\right)$; BMP $2 / 4$ and TGF- $3\left(\mathrm{r}_{\mathrm{s}}=0.632 ; p<0.01\right)$; BMP $2 / 4$ and OPG $\left(\mathrm{r}_{\mathrm{s}}=\right.$ $0.683 ; p<0.01)$ in the cartilage of the CLP group (see Table 5).

Table 5. Summary of Spearman's rank correlation analysis. Strong and moderate relationships between numbers of positive factors in the bone of the CLP group are shown

\begin{tabular}{|c|c|c|c|}
\hline Factor 1 & Factor 2 & $r_{s}$ & $\mathrm{p}$ \\
\hline MMP-2 & bFGF & 0.612 & $<0.01$ \\
\hline TIMP-2 & TGF- $\beta$ & 0.663 & $<0.01$ \\
\hline TIMP-2 & BMP 2/4 & 0.631 & $<0.01$ \\
\hline BMP 2/4 & TGF- $\beta$ & 0.632 & $<0.01$ \\
\hline BMP $2 / 4$ & OPG & 0.683 & $<0.01$ \\
\hline MMP-2 & TGF-B & 0.592 & $<0.01$ \\
\hline MMP-2 & Wnt3a & 0.484 & $<0.01$ \\
\hline TIMP-2 & bFGF & 0.457 & $<0.01$ \\
\hline TIMP-2 & Runx2 & 0.464 & $<0.01$ \\
\hline TIMP-2 & OPG & 0.572 & $<0.01$ \\
\hline BMP 2/4 & Wnt3a & 0.496 & $<0.01$ \\
\hline BMP $2 / 4$ & Runx2 & 0.409 & $<0.01$ \\
\hline bFGF & TGF- $\beta$ & 0.536 & $<0.01$ \\
\hline bFGF & OPG & 0.578 & $<0.01$ \\
\hline
\end{tabular}

For abbreviations see Table 3. 
Statistically significant $(p<0.05)$ moderate $\left(r_{\mathrm{s}}=0.4-0.59\right)$ correlations were found between MMP-2 and TGF- $\beta\left(\mathrm{r}_{\mathrm{s}}=\right.$ 0.592; $p<0.01)$; MMP-2 and Wnt3a $\left(\mathrm{r}_{\mathrm{s}}=0.484 ; p<0.01\right)$; TIMP-2 and bFGF $\left(\mathrm{r}_{\mathrm{s}}=0.457 ; p<0.01\right)$; TIMP-2 and Runx2 $\left(\mathrm{r}_{\mathrm{s}}=0.464 ; p<0.01\right)$; TIMP-2 and OPG $\left(\mathrm{r}_{\mathrm{s}}=0.572\right.$; $p<0.01)$; BMP 2/4 and Wnt3a $\left(\mathrm{r}_{\mathrm{s}}=0.496 ; p<0.01\right)$; BMP $2 / 4$ and Runx2 ( $\left.\mathrm{r}_{\mathrm{s}}=0.409 ; p<0.01\right)$; bFGF and TGF- $B\left(\mathrm{r}_{\mathrm{s}}=\right.$ 0.536; $p<0.01)$; bFGF and OPG $\left(\mathrm{r}_{\mathrm{s}}=0.578 ; p<0.01\right)$ in the cartilage of the CLP group.

\section{DISCUSSION}

In this study, we sought to understand the mechanisms that participate in bone and cartilage remodelling in CLP patients and possible outcomes related to tissue healing after a surgical intervention. Bone repair after surgical intervention depends on the coordinated action of multiple tissue regeneration factors. The numbers and distribution of the tissue factors that may have a role in regeneration have not been widely investigated.

OPG is the main osteoclastogenesis modulator, also known as inhibitor of terminal differentiation and activation of osteoclasts (Hsu et al., 2005). Periodontal ligament stem cells of rabbits expressing human OPG achieved earlier mineralisation and gained more bone formation that could help to reconstruct alveolar bone defect ( $\mathrm{Su}$ et al., 2015). There is evidence that endogenous OPG protects against cartilage destruction in osteoarthritis (Shimizu et al., 2007). In contrast, Takegami et al. (2017) found that OPG may play a part in the opposite mechanism - progression of the cartilage degeneration that is seen in inflamed intravertebral discs (Takegami et al., 2017). Although our study showed no statistically significant difference between the CLP group and the control group, more pronounced numbers of OPG positive cells were found in chondrocytes of CLP patient cartilage in comparison to bone. Correlations found between OPG and bFGF and BMP2/4 could indicate increased cartilage tissue proliferation instead of mineralisation.

Runx is necessary for the correct structure of osteoblast cells. It promotes bone mineralisation, osteoblast proliferation and induces mesenchymal cell differentiation into immature osteoblasts until the final stage of the process in which maturity of osteoblasts is inhibited (Dos Santos Pereira et al., 2017). Our results indicated that there was no statistically significant difference between the CLP group and the control group, but the numbers of Runx 2 positive structures in the bone and cartilage tissue was low, indicating reduced mineralisation potential of the hard tissue. Similar results were reported by Stricker et al. (2002) where Runx2 negative chicken embryos showed a decrease of endochondral ossiffication, which was caused by delay in chondrocyte maturation.

Wnt3a signalling increases bone formation through the stimulation of the development of osteoblasts, and inhibition of osteoblast and osteocyte apoptosis (Krishnan et al., 2006). Variation in Wnt3a, which is one of factors responsi- ble for neural crest cell development and migration, is associated with CLP (Chiquet et al., 2008). In our study there was no statistically significant difference in Wnt3a positive cells between the CLP group and the control group, but we found a difference in relative numbers between bone and cartilage tissue. The lower number of Wnt3a-positive structures in bone could result in decreased mineralisation and ossification ability in comparison to cartilage where a moderate number of positive structures was observed. Therefore we assume that the initial ossification process could take place in the cartilage tissue for patients with CLP.

MMPs are responsible for tissue remodellation, degradation of ECM, cell proliferation, and tissue repair. Absence in MMP-2 can lead to loss of bone mineral density, cartilage destruction, and abnormal craniofacial development with decreases in osteoblast and osteoclast numbers in vivo, leading to impaired skeletal development (Mosig et al., 2007). A recent study demonstrated that loss of MMP in mice concludes with dentoalveolar tissue defect (Xu et al., 2016). This concurs with another study that demonstrated increased MMP-2 expression in the bone healing process by osteoblasts and osteocytes (Itagaki et al., 2008). In our study we observed a statistically significant $(p<0.05)$ increased amount of MMP-2 in CLP patients, both in cartilage and bone, compared to the control group, which could show that alveolar bone and nasal cartilage remodellation and healing is more pronounced in CLP patients. That could mean that tissue are more requisite for tissue repair and increased levels of MMP-2-positive cells could indicate the beginning of healing after surgical intervention. Strong correlation between MMP-2 and TGF- $\beta$ ( $\mathrm{rs}=0.602$ ) in bone and MMP-2 and bFGF (rs = 0.612) in cartilage would support the process of increased tissue proliferation and remodellation.

TIMPs have the ability to inhibit the activity of MMPs and have effects on growth, survival, migration, and differentiation, and have an essential role in formation and maturation of the bone (Yoshiba et al., 2007). TIMP-2 inhibits bone resorption and degradation of the organic matrix, which mainly consists of collagen I, therefore, remodelling bone. An imbalance of active MMPs over TIMPs is responsible for increased bone loss in pathological processes (Hill et al., 1993). It has been found that osteoblasts and osteocytes in the incorporated bone also increasingly express TIMP2 (Hatori et al., 2004). Polymorphism in TIMP2 is associated with the development of facial clefts (Letra et al., 2012). In our research no statistically significant difference was found between the CLP group and the control group, but the increased levels of TIMP2 and strong correlations between TIMP2 and BMP2/4 (rs = 0.602) and TIMP2 and TGF-B (rs $=0.602$ ) in chondrocytes in comparison to osteocytes may suggest better healing potential in the cartilage.

TGF- $\beta$ acts as inhibitor for MMP activity and increases the activity of TIMPs, therefore it inhibits collagen degradation and stimulates collagen production (Mitchell, 2017). TGF- 3 negatively regulates osteoclastogenesis by increasing levels of OPG in osteoblasts. The addition of TGF- $\beta$ as exogenous 
applications in orthodontic treatment may be an approach to prevent periodontal damage (Yang et al., 2014). In our study, there was no statistically significant difference between the CLP group and the control group in TGF- 3 -positive cells. However, larger numbers of TGF- $\beta$ were found in cartilage, therefore indicating better tissue regeneration ability.

FGFs are potent angiogenic factors and have an important role in embryonic development and wound healing, angiogenesis, tissue repair and regeneration (Powers et al., 2000). FGF signalling participates in all stages of palatogenesis, especially in cell proliferation during palatal fusion, and disturbance of this process in the central neural crest would cause a failure of palatal shelf fusion and would result in CLP (Weng et al., 2018). A greater amount of new cementum deposits and new bone formation was observed six weeks after bFGF applications to bone defects created in dogs (Murakami et al., 2003). In our study, we observed a statistically significant $(p<0.05)$ increase in amount of bFGF in the cartilage and bone of the CLP patients in comparison to the control group. These observations may suggest that increased proliferation and hypertrophy takes place in both chondrocytes and osteocytes in CLP patients, which could indicate a better possibility for successful wound healing.

BMP signal is critical for sceletogenesis due to regulation of chondrogenesis and osteogenesis. BMP signalling is involved in determination, migration, proliferation, differentiation and apoptosis of skeletal cells (Nie et al., 2006). Disturbance in BMP-4 signalling pathways and genetic polymorphisms presented with diminished cell proliferation in maxillary process mesenchyme (Liu et al., 2005) and is clinically significant in the development and progression of CLP (Lin et al., 2008). It is concluded that BMP applications could influence endochondral ossification, thereby accelerating fracture healing (Wang et al., 2017) and also it has properties to increase proteoglycans and collagen production in the bone at the place of osteoplasty (Sekiya et al., 2005). BMP-2 has the ability to induce mesenchymal cells to differentiate into osteoblast cells. Herford et al. showed that premaxillary osseous clefts, repaired with the material filled with BMP-2, could result in efficacious bone repair without autogenous bone carrier graft (Herford et al., 2007). There was no statistically significant difference found between the CLP group and the control group for bone, but a statistically significant $(p=0.012)$ increased amount of BMP 2/4 was found in the cartilage of the CLP patients in comparison to the controls. We obtained statistically significant strong correlations between BMP2/4 and TIMP2 (rs = $0.631)$ and BMP2/4 and TGF- $\beta$ (rs = 0.632) which may suggest increased tissue proliferation and healing capacities in cartilage that exceeds bone healing.

\section{CONCLUSIONS}

Increased appearance of MMP2, bFGF positive structures in hard tissue of the CLP patients indicates the predominance of tissue degradation of mesodermal origin tissue.
Increased number of BMP2/4 positive chondrocytes suggests the elevation of cartilage growth and thus better regeneration in the cleft lip palate.

Slight predominance of OPG, Wnt3a, TIMP2, TGF-ß-positive structures in cartilage (although without the statistically significant difference) proves the tendency for higher cartilage plasticity, including regeneration in cleft affected tissue.

The observed low number of OPG and Runx2 positive cells in bone could indicate a reduced mineralisation potential in bone in the case of CLP.

\section{ACKNOWLEDGMENTS}

Rìga Stradiňs University kind support for the research is highly acknowledged.

This study was funded by Rīga Stradiň̌ University, No. 5-1/106/2019 from 12.04.2019, "The elaboration of diagnostic prognostic factor algorithm of facial tissue complex regeneration for cleft patients in longitudinal aspect".

\section{REFERENCES}

Akota, I., Barkāne, B., Grasmane, N. (2001). Iedzimto sejas šķeltnuu biežuma rādītāji Latvijā no 1960. līdz 1997. gadam [Frequency indicators of congenital facial clefts in Latvia in 1960-1997]. Grām.: LMA/RSU Zinātniskie raksti. Rīga: LMA/RSU, 2001, 166.-170. 1pp. (in Latvian).

Charoenlarp, P., Rajendran, A. K., Iseki S. (2017). Role of fibroblast growth factors in bone regeneration. Inflamm. Regener., 37 (10), 1-7.

Chiquet, B. T., Blanton, S. H., Burt, A., Ma, D., Stal, S., Mulliken, J. B., Hecht, J. T. (2008). Variation in WNT genes is associated with non-syndromic cleft lip with or without cleft palate. Hum. Mol. Genet., 17 (14), 2212-2218.

Dallas, S. L., Rosser, J. L., Mundy, G. R., Bonewald, L. F. (2002). Proteolysis of latent transforming growth factor-(TGF-)-binding protein-1 by osteoclasts. A cellular mechanism for release of TGF from bone matrix. $J$. Biol. Chem., 277 (24), 21352-21360.

Dos Santos Pereira, R. S., Boos, F. B., Gorla, L. F., Garcia I. R., Okamoto, R., Hochuli-Vieira, E. (2017). Maxillary sinus elevation surgery with chronOS and autogenous bone graft: Immunohistochemical assessment of RUNX2, VEGF, TRAP, and osteocalcin. Int. J. Periodontics Restorative Dent., 37 (6), 321-327.

Faßbender, M., Minkwitz, S., Strobel, C., Schmidmaier, G., Wildemann, B. (2014). Stimulation of bone healing by sustained bone morphogenetic protein 2 (BMP-2) delivery. Int. J. Mol. Sci., 15, 8539-8552.

Hartmann, C. (2006). A Wnt canon orchestrating osteoblastogenesis. Trends Cell. Biol., 16, 151-158.

Hatori, K., Sasano, Y., Takahashi, I., Kamakura, S., Kagayama, M., Sasaki, K. (2004). Osteoblasts and osteocytes express MMP2 and -8 and TIMP1, -2 , and -3 along with extracellular matrix molecules during appositional bone formation. Anat. Rec. Part A, 277, 262-271.

Herford, A. S., Boyne, P. J., Rawson, R., Williams, R. P. (2007). Bone morphogenetic protein-induced repair of the premaxillary cleft. J. Oral Maxillofac. Surg., 65 (11), 2136-2141.

Hill, P. A., Reynolds, J. J., Meikle, M. C. (1993). Inhibition of stimulated bone resorption in vitro by TIMP-1 and TIMP-2. Biochim. Biophys. Acta.: Mol. Cell Res., 1177 (1), 71-74.

Gaur, T., Lengner, C. J., Hovhannisyan, H., Bhat, R. A., Bodine, P. V. N., Komm, B. S., Javed A., Wijnen, A. J., Stein, J. L., Stein, G. S., Lian J. B. 
(2005). Canonical WNT signaling promotes osteogenesis by directly stimulating Runx2 gene expression. J. Biol. Chem., 280 (39), 33132-33140.

Gkantidis, N., Katsaros, C., Chiquet, M. (2012). Detection of gelatinolytic activity in developing basement membranes of the mouse embryo head by combining sensitive in situ zymography with immunolabeling. Histochem. Cell Biol., 138, 557-571.

Hsu, Y. H., Niu, T., Terwedow, H. A., Xin, X., Feng, Y., Zhiping, L., Brain, J. D., Rosen, C. J., Laird, N., Xu, X. (2006). Variation in genes involved in the RANKL/RANK/OPG bone remodeling pathway are associated with bone mineral density at different skeletal sites in men. Hum. Gen., 118 (5), 568-577.

Itagaki, T., Honma, T., Takahashi, I., Echigo, A., Sasano, Y. (2008). Quantitative analysis and localization of mRNA transcripts of type I collagen, osteocalcin, MMP 2, MMP 8, and MMP 13 during bone healing in a rat calvarial experimental defect model. Anat. Rec., 291, 1038-1046.

Kang, J. H., Ko, H. M., Moon, J. S., Yoo, H. I., Jung, J. Y., Kim, M. S., Kim, S. H. (2014). Osteoprotegerin expressed by osteoclasts: An autoregulator of osteoclastogenesis. J. Dental Res., 93 (11), 1116-1123.

Komori, T. (2006). Regulation of osteoblast differentiation by transcription factors. J. Cell Biochem., 99, 1233-1239.

Krishnan, V., Bryant, H. U., Macdougald, O. A. (2006). Regulation of bone mass by Wnt signaling. J. Clin. Investig., 116 (5), 1202-1209.

Kumar, V., Abbas, A., Aster J. (2014). Robbins and Cotran pathologic basis of disease. $9^{\text {th }}$ edition. Elsevier. 1408 pp. Chapter 1, 1-29 pp.

Kwan, T. S., Pelletier, J. P., Lajeunesse, D., Fahmi, H., Lavigne, M., MartelPelletier, J. (2008). The differential expression of osteoprotegerin (OPG) and receptor activator of nuclear factor kappaB ligand (RANKL) in human osteoarthritic subchondral bone osteoblasts is an indicator of the metabolic state of these disease cells. Clin. Exp. Rheumatol., 26 (2), 295-304.

Letra, A., Silva, R. M., Motta, L. G., Blanton, S. H., Hecht, J. T., Granjeirol, J. M., Vieira, A. R. (2012). Association of MMP3 and TIMP2 promoter polymorphisms with nonsyndromic oral clefts. Birth Defects Res. Part A: Clin. Mol. Teratology, 94 (7), 540-548.

Letra, A., Silva, R. M., Rylands, R. J., Silveira, M. S., Souza, A. P., Wendell, S. K., Garlet G. P., Vieira, A. R. (2012). MMP3 and TIMP1 variants contribute to chronic periodontitis and may be implicated in disease progression. J. Clin. Periodont., 39 (8), 707-716.

Li, C., Lan, Y., Jiang, R. (2017). Molecular and cellular mechanisms of palate development. J. Dental Res., 96 (11), 1184-1191.

Li, L., Wang, Y., Lin, M., Yuan, G., Yang, G., Zheng, Y., Chen, Y. (2013). Augmented BMPRIA-mediated BMP signaling in cranial neural crest lineage leads to cleft palate formation and delayed tooth differentitation. PloS ONE, 8 (6), 1-9.

Lin, J.-Y., Chen, Y.-J., Huang, Y.-L., Tang, G.-P., Zhang, L., Deng, B., Li, M., Ma, H., Luan, R.-S. (2008). Association of bone morphogenetic protein 4 gene polymorphisms with nonsyndromic cleft lip with or without cleft palate in Chinese children. DNA Cell Biol., 27 (11), 601-605.

Liu, W., Sun X., Braut A., Mishina Y., Behringer R. R., Mina M., Martin J. F. (2005). Distinct functions for Bmp signaling in lip and palate fusion in mice. Development, 132 (6), 1453-1461.

Logan, C. Y., Nusse, R. (2004). The Wnt signaling pathway in development and disease. Annu. Rev. Cell Devel. Biol., 20, 781-810.

Mosig, R. A., Dowling, O., DiFeo, A., Ramirez, M. C. M., Parker, I. C., Abe, E., Martignetti, J. A. (2007). Loss of MMP-2 disrupts skeletal and craniofacial development and results in decreased bone mineralization, joint erosion and defects in osteoblast and osteoclast growth. Human Mol. Gen., 16 (9), 1113-1123.

Murakami, S., Takayama, S., Kitamura, M., Shimabukuro, Y., Yanagi, K., Ikezawa, K., Saho, T., Nozaki, T., Okada, H. (2003). Recombinant human basic fibroblast growth factor (bFGF) stimulates periodontal regeneration in class II furcation defects created in beagle dogs. J. Periodontal Res., 38, 97-103.

Murray, J. (2002). Gene/environment causes of cleft lip or palate. Clin. Gen., 61, 248-256.

Norton, N. S. (2016). Netter's Head and Neck Anatomy for Dentistry. $3^{\text {rd }}$ Edition. Elsevier. 712 pp.

Nie, X., Luukko, K., Kettunen, P. (2006). BMP signalling in craniofacial development. Int. J. Dev. Biol., 50, 511-521.

Pilmane M., Šūmahers G. H. (2006). Medicīniskā embrioloǵija [Medical embriology]. Rīgas Stradiņa universitāte, Rīga. 335 lpp. (in Latvian).

Powers, C. J., McLeskey, S. W., Wellstein, A. (2007). Fibroblast growth factors, their receptors and signaling. Endocr. Relat. Cancer, 7, 165-197.

Sekiya, I., Larson, B. L., Vuoristo, J. T., Reger R. L., Prockop D. J. (2005) Comparison of effect of BMP-2, -4 , and -6 on in vitro cartilage formation of human adult stem cells from bone marrow stroma. Cell Tissue Res., 320, 269-276.

Shimizu, S., Asou, Y., Itoh, S., Chung, U. I., Kawaguchi, H., Shinomiya, K., Muneta, T. (2007). Prevention of cartilage destruction with intraarticular osteoclastogenesis inhibitory factor/osteoprotegerin in a murine model of osteoarthritis. Arthritis Rheum., 56 (10), 3358-3365.

Stricker, S., Fundele, R., Vortkamp, A., Mundlos, S. (2002). Role of Runx genes in chondrocyte differentiation. Devel. Biol., 245, 95-108.

Su, F., Liu, S. S., Ma, J. L., Wang, D. S., E, L. L., Liu, H. C. (2015). Enhancement of periodontal tissue regeneration by transplantation of osteoprotegerin-engineered periodontal ligament stem cells. Stem Cell Res. Ther., 6 (22), 1-20.

Takegami, N., Akeda, K., Yamada, J., Sano, T., Murata, K., Huang, J., Masuda, K., Sudo, A. (2017). RANK/RANKL/OPG system in the intervertebral disc. Arthritis Res. Ther., 19 (1), 121.

Tiwana, P. S., Turvey, T. A., Ruiz, R. L., Costello, B. J., Panchel, N. H. (2018). Oral and Maxillofacial Surgery. 596-608 pp.

Verstappen, J., Von den Hoff, J. W. (2006). Tissue inhibitors of metalloproteinases (TIMPs): Their biological functions and involvement in oral disease. J. Dent. Res., 85 (12), 1074-1084.

Xu, H., Snider, T. N., Wimer, H. F., Yamada, S. S., Yang, T., Holmbeck, K., Foster, B. L. (2016). Multiple essential MT1-MMP functions in tooth root formation, dentinogenesis, and tooth eruption. Matrix Biol. J. Int. Soc. Matrix Biol., 52-54, 266-283.

Wang, P., Ying, J., Luo, C., Jin, X., Zhang, S., Xu, T., Zhang, L., Mi, M., Chen, D., Tong, P., Jin, H. (2017). Osthole promotes bone fracture healing through activation of BMP signaling in chondrocytes. Int. J. Biol. Sci., 13 (8), 996-1007.

Weng, M., Chen, Z., Xiao, Q., Li, R., Chen, Z. (2018). A review of FGF signaling in palate development. Biomed. Pharmacother., 103, 240-247.

Xuguang, N., Luukko, K., Kettunen, P. (2006). BMP signalling in craniofacial development. Int. J. Dev. Biol., 50, 511-521.

Yang, X., Wang, Y., Han, X., Shu, R., Chen, T., Zeng, H., Xu, X., Huang, L., Ren, A., Song, J., Cao, L., Bai, D. (2015). Effects of TGF-ß 1 on OPG/RANKL expression of cementoblasts and osteoblasts are similar without stress but different with mechanical compressive stress. Sci. World J., 718180, 1-12.

Yoshiba, N.,Yoshiba, K., Hosoya, A., Saito, M., Yokoi, T., Okiji, T., Amizuka, N., Ozawa, H. (2007). Association of TIMP-2 with extracellular matrix exposed to mechanical stress and its co-distribution with periostin during mouse tooth development. Cell Tissue Res., 330, 133-145.

Zhang, X., Liu, Y., Wang, X., Sun, X., Zhang, C., Zheng, S. (2017). Analysis of novel RUNX2 mutations in Chinese patients with cleidocranial dysplasia. PLOS ONE, 12 (7), 1-6. 


\section{AUDU REMODELĀCIJAS FAKTORU SASTOPAMĪBA UN ATRADNE LŪPU UN AUKSLĒJU ŠKELTNUU PACIENTU BALSTAUDOS}

Kaulu dzišana pēc lūpu un aukslēju šķeltṇu k̦irurğiskas korekcijas ir atkarīga no vairāku faktoru savstarpējas mijiedarbības. Šajā pētījumā tika novērtēts audu faktoru (MMP-2, TIMP-2, BMP 2/4, TGF- $\beta$, Wnt3a, Runx2, bFGF un OPG) relatīvais daudzums škeltnes skartu pacientu un kontroles grupas balstaudos. Pētījumā tika iekḷauti 43 lūpas un aukslēju šḳeltnes skarti pacienti un analizēti 24 kaulaudu paraugi un 36 skrimšḷaudu paraugi. Kontroles grupas materiāls tika iegūts ar šķeltni nesaistītu operāciju rezultātā. Imūnhistokị̄miski noteikto un analizēto struktūru kvantifikācijai tika izmantota puskvantitatīvā skaitīšanas metode. Šḳeltnes pacientu kaulaudos un skrimšlaudos tika novērots palielināts MMP-2 un bFGF pozitīvo šūnu daudzums, salīdzinot ar kontroles grupu, kas norāda uz audu degradācijas predominanci šḳeltnes pacientu balstaudos. BMP 2/4 pozitīvo šūnu daudzums šḳeltnes pacientu skrimšḷaudos bija statistiski ticami lielāks $(p=0,012)$ nekā kontroles grupas pacientiem. Palielināts BMP2/4 pozitīvo šūnu daudzums šḳeltnes skartu pacientu skrimšlaudos norāda uz palielinātu skrimšlı augšanu un tādējādi labāku skrimšḷa reǵenerāciju lūpas un aukslēju šķeltnes pacientiem. Samazināts OPG un Runx2 pozitīvo šūnu daudzums škeltnes pacientu kaulaudos varētu norādīt uz samazinātu kaula mineralizācijas potenciālu. Aukslēju šķeltṇu gadījumā audu proliferācijas un remodelēšanas procesi dominē pār mineralizācijas procesu. 